\title{
PENGARUH VARIASI KADAR SERAT DAN RASIO PANJANG TERHADAP DIAMETER (L/D) SERAT PELEPAH SAWIT TERHADAP KUAT TEKAN DAN KUAT TARIK BELAH BETON SERAT
}

\author{
Haryadi Saputra ${ }^{1}$, Liliana Sahay ${ }^{2}$, dan Frieda ${ }^{3}$ \\ ${ }^{123}$ Program Studi Teknik Sipil, Fakultas Teknik, Universitas Palangka Raya \\ E-mail: haryadisaputra07@gmail.com, lilianasahay@yahoo.co.id, dan \\ friedatekniksipil@gmail.com/HP.+6282299602089
}

\begin{abstract}
ABSTRAK
Beton salah satu material konturuksi mampu memikul beban tekan, tetapi lemah dalam menerima beban tarik. Hal ini menyebabkan beton bersifat getas dan dapat. mengakibatkan keruntuhan mendadak sehingga serat digunakan pada beton. Tetapi bukan berarti beton tidak mengalami keruntuhan tarik. Dengan penambahan serat pelepah kelapa sawit yang merupakan bahan lokal, diharapkan dapat memperbaiki kelemahan beton. Variasi kadar atau presentase serat kelapa sawit yang ditambahkan ke dalam campuran beton adalah sebesar $1 \%, 1,5 \%$ dan $2 \%$ dari total berat semen beton silinder. Hasil Penelitian kuat tekan, penambahan dan semakin besar 1/d serat pelepah kelapa sawit tidak memberikan pengaruh yang signifikan terhadap peningkatan kuat tekan, kuat tekan tertinggi di peroleh pada rasio $1 / \mathrm{d}=50$ dengan kadar serat $1 \%$ dengan nilai kuat tekan sebesar 14,33 MPa. Pada Pengujian kuat tarik belah beton tertinggi pada kadar serat $1 \%$ dengan rasio $1 / \mathrm{d}=50$ nilai kuat tarik yang dihasilkan sebesar 2,10 MPa pada umur 7 hari.
\end{abstract}

Kata kunci: beton serat, kuat tekan, pelepah kelapa sawit, kuat tarik belah,

\begin{abstract}
Concrete one of the contour materials is able to shoulder the load press, but is weak in accepting tensile loads. This causes the concrete to be sap and can be. resulting in sudden collapse so that fibers are used on concrete. But that doesn't mean concrete doesn't suffer a pull collapse. With the addition of palm oil fiber which is a local material, it is expected to improve concrete weakness. Variations in the content or percentage of palm fibers added to the concrete mixture are $1 \%, 1.5 \%$ and $2 \%$ of the total weight of cylindrical concrete cement. The results of the study of strong press, addition and greater L/d fiber palm oil fronds did not have a significant influence on the increase in press strength, the highest compressive strength obtained at the ratio of $1 / \mathrm{d}=50$ with a fiber content of $1 \%$ with a strong press value of $14.33 \mathrm{MPa}$. In strong testing the highest concrete pull at fiber content of $1 \%$ with a ratio of $1 / \mathrm{d}=50$ tensile strength values produced by $2.10 \mathrm{MPa}$ at the age of 7 days.
\end{abstract}

Keywords: concrete fiber, strong press, palm fronds, strong pull.

\section{PENDAHULUAN}

Beton merupakan salah satu material kontruksi yang digunakan pada bangunan gedung, jembatan, dan lain-lainnya. Beton terdiri dari campuran agregat halus (pasir), agregat kasar (kerikil), air, dan semen serta dengan atau tanpa bahan tambah (admixture) menurut 
(Kardiyono Tjokrodimulyo, 2007). Salah satu bahan tambah dalam campuran beton adalah serat yang kemudian dikenal dengan istilah beton serat.

Beton serat (fiber concrete) adalah bahan komposit yang terdiri dari beton dan bahan lainnya berupa serat. Serat dalam beton ini berfungsi mencegah retak-retak dan memperbaiki sifat beton yang lemah terhadap tarik (Kardiyono Tjokrodimulyo, 2007). Berdasarkan data Badan Pusat Statistik (2018) perkebunan kelapa sawit yang dimiliki oleh provinsi kalimantan tengah dengan luasan sekitar 1.508.215,55 hektar. Dengan luasan perkebunan yang tercantum tersebut maka limbah pelepah kelapa sawit yang dihasilkan pertahun sebesar 56.250.407,15 ton/tahun. Setiap pemanenan dari satu pohon kelapa sawit menghasilkan dua pelepah kelapa sawit yang harus dipangkas karena ketersediaan limbah tersebut cukup banyak, maka perlu pemanfaatan secara langsung pada campuran beton.

Menurut Zainuru, dkk (2017), memanfaatkan serat pelepah kelapa sawit asal Dumai sebagai bahan tambah dalam pembuatan batako serat. Dengan memvariasikan serat yang dilakukan sebesar 1\%, 3\%, dan 5\%. Dengan rasio pada rendaman $\mathrm{NaOH} 30 \mathrm{~g} / \mathrm{L}$ dan serat pelepah kering dipotong-potong dengan ukuran kurang lebih $20 \mathrm{~mm}$ sebelum digunakan dalam campuran batako. Dalam penelitan ini didapatkan bahwa nilai kuat tekan dan penyerapan air batako serat yang berasal dari Dumai lebih baik pada penambahan serat $1 \%$ dari berat semen yang memenuhi persyaratan mutu SNI dengan kuat tekan sebesar $11,08 \mathrm{MPa}$ dan penyerapan air 3\% pada penambahan serat $1 \%$.

Amna, dkk (2014), penambahan serat dari tandan kosong kelapa sawit tidak memberikan pengaruh terhadap peningkatan kuat tekan beton, namun memberikan pengaruh pada peningkatan kuat lentur beton.

Ginting, dkk (2014), melakukan penelitian dengan menggunakan pelepah kelapa sawit yang direndam dengan air panas, air dingin selama 3 hari kemudian direndam dalam laruran $1 \% \mathrm{NaOH}$ selama 24 jam untuk dijadikan serat sebagai bahan pengisi dalam pembuataan batako. Dikatakan bahwa penambahan $6 \%$ serat pelepah kelapa sawit dengan panjang $25 \mathrm{~mm}$ memberikan kuat tekan batako yang maksimum sebesar 2,89 Mpa.

Hafiz, dkk (2015) menambahkan serat bendrat untuk mengkaji sifat mekanik beton serat, menyatakan bahwa pemakaian serat dengan rasio panjang terhadap diameter (L/D) sebesar 12,5 dapat meningkatkan kuat tarik dan kuat geser beton dengan penambahan serat bendrat sebanyak $3 \%$ dari berat volume. Kuat tarik terbesar 2,41 $\mathrm{MPa}$ atau meningkat 2 kali dari beton tanpa serat, sedangkan untuk kuat geser maksimal mencapai 4,94 MPa dengan kenaikan 54\% dibandingkan dengan beton tanpa serat.

Sudarmoko (1989), mengatakan bahwa batas maksimal aspek ratio fiber yang masih memungkinkan pengadukan dilakukan dengan mudah adalah $1 / \mathrm{d}<100$. Nilai $1 / \mathrm{d}$ yang melampaui batas di atas akan menyebabkan kesulitan dalam pengadukan. Aspek ratio fiber yang tinggi akan menyebabkan fiber cenderung untuk menggumpal (balling effect) menjadi suatu bola yang sangat sulit disebar secara merata sebelum dan sesudah proses pengadukan.

Dari penelitian di atas, maka dalam penelitian ini akan dikaji pemakaian pelepah kelapa sawit yang direndam dalam larutan $\mathrm{NaOH} 30 \mathrm{~g} / \mathrm{L}$ untuk dijadikan serat dan dicampurkan 
untuk mendapatkan beton serat. Kajian eksperimental dilakukan dengan melakukan variasi kadar serat dan rasio panjang terhadap diameter serat (L/D) pelepah kelapa sawit untuk dijadikan campuran beton serat.

\section{Tujuan penelitian :}

1. Mengetahui pengaruh rasio panjang terhadap diameter serat (L/D) dari serat pelepah kelapa sawit yang dicampurkan kedalam beton terhadap kuat tekan beton.

2. Mengetahui pengaruh variasi kadar serat tersebut terhadap kuat tekan beton.

3. Mengetahui kuat tekan dan kuat tarik belah beton yang dihasilkan dari bahan tambah serat pelepah kelapa sawit.

\section{METODE PENELITIAN}

\section{Lokasi dan Objek Penelitian}

Penelitian ini di lokasi Laboratorium Bahan dan Struktur Jurusan Teknik Sipil Fakultas Teknik Universitas Palangka Raya Provinsi Kalimantan Tengah dengan objek penelitian serat pelepah kelapa sawit dari perkebunan kelapa sawit di Desa Bereng Jun, Kabupaten Gunung Mas, Indonesia.

\section{Material}

Material yang digunakan dalam penelitian ini adalah:

1. Semen

Semen yang digunakan adalah semen Portland komposit Type 1.

2. Air

Air yang digunakan adalah air keran yang berasal dari laboratorium.

3. Agregat halus

Agregat halus yang digunakan berupa pasir yang berasal dari tangkiling dan telah memenuhi persyaratan tes kebersihan terhadap lumpur berdasarkan ASTM C 33.

4. Agregat kasar

Agregat kasar yang digunakan berupa batu pecah yang berasal dari mandiangin Kalimantan selatan dan telah memenuhi persyaratan tes kebersihan terhadap lumpur berdasarkan ASTM C 33.

5. Serat yang digunakan adalah serat pelepah kelapa sawit dari perkebunan dengan panjang serat sebesar $20 \mathrm{~mm}, 40 \mathrm{~mm}$, dan $60 \mathrm{~mm}$.

\section{Variabel Penelitian}

Variabel penelitian meliputi variabel tetap dan berubah. Variabel tetap yaitu ukuran beton serat dengan diameter $100 \mathrm{~mm}$ dan tinggi $200 \mathrm{~mm}$. Sedangkan variabel berubah yaitu terdiri dari konsentrasi rasio panjang serat terhadap diameter serat (L/D). Perbandingan serat pelepah kelapa sawit dalam beton dengan memvariasikan kadar serat $0 \%, 1 \%, 1,5 \%$ dan $2 \%$ dari berat semen dengan waktu pengerasan 7 dan 28 hari.

\section{Variasi Campuran Beton Serat}

Dalam penelitian ini terdapat 4 (empat) macam variasi campuran beton serat. Variasi tersebut dibedakan berdasarkan jumlah persentase serat pelepah kelapa sawit terhadap kebutuhan berat semen yang dimasukkan pada campuran beton. Variasi persentase serat 
yang digunakan adalah $0 \%$ (sebagai beton acuan), 1\%, 1,5\% dan 2\%. Proporsi campuran beton serat dapat dilihat pada table 3.1 dan jumlah perkiraan benda uji untuk 4 (empat) macam variasi campuran beton serat.

Tabel 1. Komposisi Jumlah Sampel

\begin{tabular}{|c|c|c|c|c|c|}
\hline & \multirow{2}{*}{$\begin{array}{c}\text { Kadar } \\
\text { Serat } \\
(\%) \\
\end{array}$} & \multirow{2}{*}{$\begin{array}{c}\mathbf{L} \\
\mathbf{m m})\end{array}$} & \multirow[t]{2}{*}{ D (mm) } & \multirow{2}{*}{$\begin{array}{c}\text { Rasio } \\
\text { L/D } \\
(\%)\end{array}$} & \multirow{2}{*}{$\begin{array}{l}\text { Jumlah } \\
\text { Sampel }\end{array}$} \\
\hline & & & & & \\
\hline Variasi 1 & 0 & 0 & 0 & 0 & 3 Buah \\
\hline \multirow[t]{3}{*}{ Variasi 2} & 1 & 20 & 0,4 & 50 & 3 Buah \\
\hline & & 40 & 0,4 & 100 & 3 Buah \\
\hline & & 60 & 0,4 & 150 & 3 Buah \\
\hline \multirow[t]{3}{*}{ Variasi 3} & 1,5 & 20 & 0,4 & 50 & 3 Buah \\
\hline & & 40 & 0,4 & 100 & 3 Buah \\
\hline & & 60 & 0,4 & 150 & 3 Buah \\
\hline \multirow[t]{3}{*}{ Variasi 4} & 2 & 20 & 0,4 & 50 & 3 Buah \\
\hline & & 40 & 0,4 & 100 & 3 Buah \\
\hline & & 60 & 0,4 & 150 & 3 Buah \\
\hline
\end{tabular}

Sumber: Penulis (2020)

\section{HASIL DAN PEMBAHASAN}

\section{Karakteristik Hasil Agregat Kasar}

Tabel 2. Hasil Agregat Kasar

\begin{tabular}{|c|l|c|c|}
\hline No & \multicolumn{1}{|c|}{ Pengujian } & Hasil & Satuan \\
\hline \multirow{4}{*}{1} & Analisa saringan & & \\
\cline { 2 - 4 } & - Modulus Kehalusan & 6,5 & $\%$ \\
\hline \multirow{4}{*}{2} & Berat jenis & & \\
\cline { 2 - 4 } & - Bulk & 2,51 & - \\
\cline { 2 - 4 } & - SSD & 2,52 & - \\
\cline { 2 - 4 } & - Apparent & 2,53 & - \\
\hline \multirow{4}{*}{3} & Berat Volume & 1,372 & $\mathrm{Kg} / \mathrm{Liter}$ \\
\cline { 2 - 4 } & - Padat & 1,352 & $\mathrm{Kg} / \mathrm{Liter}$ \\
\cline { 2 - 4 } & - Goyangan & 1,312 & $\mathrm{Kg} / \mathrm{Liter}$ \\
\cline { 2 - 4 } & - Lepas & 2,63 & $\%$ \\
\hline 4 & Kadar air & \multicolumn{2}{c}{} \\
\hline
\end{tabular}

Sumber: Hasil Pengujian (2020)

Dari hasil rekapitulasi pengujian agregat kasar memenuhi spesifikasi yang telah ditentukan. 


\section{Karakteristik Hasil Agregat Halus}

Tabel 3. Hasil Agregat Halus

\begin{tabular}{|c|c|c|c|}
\hline No & Pengujian & Hasil & Satuan \\
\hline \multirow{2}{*}{1} & Analisa saringan & & \\
\hline & $-\quad$ Modulus Kehalusan & 3,11 & $\%$ \\
\hline \multirow{4}{*}{2} & Berat jenis & & \\
\hline & - Bulk & 2,56 & - \\
\hline & $-\quad$ SSD & 2,51 & - \\
\hline & - $\quad$ Apparent & 2,5 & - \\
\hline \multirow{4}{*}{3} & Berat Volume & & \\
\hline & - $\quad$ Padat & 1,692 & $\mathrm{Kg} /$ Liter \\
\hline & - $\quad$ Goyangan & 1,676 & $\mathrm{Kg} /$ Liter \\
\hline & - $\quad$ Lepas & 1,572 & Kg/Liter \\
\hline 4 & \begin{tabular}{|l|} 
Kadar air \\
\end{tabular} & 0,08 & $\%$ \\
\hline 5 & Kadar lumpur & 22,24 & $\%$ \\
\hline
\end{tabular}

Sumber: Hasil Pengujian (2020)

Dari hasil rekapitulasi pengujian agregat halus memenuhi spesifikasi yang telah ditentukan.

\section{Hasil Pemeriksaan Slump Beton}

Tabel 4. Hasil Slump Beton

\begin{tabular}{|r|l|c|c|}
\hline No & \multicolumn{1}{|c|}{ Pengujian } & $\begin{array}{c}\text { Slump } \\
\text { Rencana (cm) }\end{array}$ & $\begin{array}{c}\text { Slump Yang } \\
\text { Didapatkan } \\
(\mathbf{c m})\end{array}$ \\
\hline 1 & Beton Konvensional & $3,0-6,0$ & 3,7 \\
\hline 2 & Beton Serat & $3,0-6,0$ & 3 \\
\hline
\end{tabular}

Sumber: Hasil Pengujian (2020)

Dari hasil pemeriksaan slump beton yang digunakan memenuhi slump rencana yaitu 3 $6 \mathrm{~cm}$, maka bisa dilanjutkan dengan pembuatan beton.

\section{Hasil Pemeriksaan Berat Isi Beton Segar}

1. Berat Isi Beton Serat

Tabel 5. Hasil Pemeriksaan Berat Isi Beton Serat

\begin{tabular}{|c|l|c|}
\hline \multicolumn{2}{|c|}{ OBSERVASI } \\
\hline No & \multicolumn{1}{|c|}{ Uraian } & Hasil \\
\hline $\mathbf{1}$ & Berat Wadah & $6,75 \mathrm{Kg}$ \\
\hline $\mathbf{2}$ & Berat Benda Uji + Wadah & $10,2 \mathrm{Kg}$ \\
\hline $\mathbf{3}$ & Volume Wadah & $0,00157 \mathrm{~m}^{3}$ \\
\hline $\mathbf{4}$ & Berat Benda Uji & $3,45 \mathrm{Kg}$ \\
\hline $\mathbf{5}$ & Berat Isi Beton Segar & $2203,82 \mathrm{~kg} / \mathrm{m} 3$ \\
\hline
\end{tabular}

Sumber : Hasil Pengujian (2020) 
Dari hasil pemeriksaan dilaboratorium diperoleh berat isi beton serat rata-rata sebesar $2203,82 \mathrm{~kg} / \mathrm{m}^{3}$. Hasil pemeriksaan memenuhi standar untuk beton normal. Standar beton normal adalah 2200-2500 kg/ $\mathrm{m}^{3}$ (Mulyono, 2003).

\section{Berat Isi Beton Konvensional}

Tabel 6. Hasil Pemeriksaan Berat Isi Beton Segar

\begin{tabular}{|c|l|c|}
\hline \multicolumn{3}{|c|}{ OBSERVASI } \\
\hline No & \multicolumn{1}{|c|}{ Uraian } & Hasil \\
\hline $\mathbf{1}$ & Berat Wadah & $1,15 \mathrm{Kg}$ \\
\hline $\mathbf{2}$ & Berat Benda Uji + Wadah & $13,1 \mathrm{Kg}$ \\
\hline $\mathbf{3}$ & Volume Wadah & $0,005 \mathrm{~m}^{3}$ \\
\hline $\mathbf{4}$ & Berat Benda Uji & $11,95 \mathrm{Kg}$ \\
\hline $\mathbf{5}$ & Berat Isi Beton Segar & $2390,00 \mathrm{Kg} / \mathrm{m} 3$ \\
\hline
\end{tabular}

Sumber: Hasil Pengujian (2020)

Dari hasil pemeriksaan dilaboratorium diperoleh berat isi beton segar yaitu sebesar $2390,00 \mathrm{~kg} / \mathrm{m}^{3}$. Hasil pemeriksaan memenuhi standar untuk beton normal. Standar beton normal adalah 2200-2500 kg/ $\mathrm{m}^{3}$ (Mulyono, 2003).

\section{Hasil Kuat Tekan Beton}

Hasil Pengujian kuat beton tanpa penambahan serat dan tambah serat serat dengan berbagai persentase penambahan serat pada umur 7 hari dan 28 hari adalah sebagai berikut:

Tabel 7. Hasil Kuat Tekan Beton Umur 7 dan 28 Hari

\begin{tabular}{|c|c|c|c|c|}
\hline & \multirow{2}{*}{$\begin{array}{c}\text { Kadar } \\
\text { Serat } \\
\end{array}$} & \multirow{2}{*}{$\begin{array}{c}\text { Rasio } \\
\text { L/D (\%) }\end{array}$} & \multicolumn{2}{|c|}{ Kuat Tekan (MPa) } \\
\cline { 4 - 5 } & & \multicolumn{2}{|c|}{ Umur (Hari) } \\
\cline { 4 - 5 } & & 0 & 19,36 & 24,33 \\
\hline Variasi 1 & 0 & 50 & 7,64 & 14,33 \\
\hline Variasi 2 & 1 & 100 & 3,82 & 11,46 \\
\hline & & 150 & 3,82 & 10,51 \\
\hline & & 50 & 6,69 & 8,6 \\
\hline Variasi 3 & 1,5 & 100 & 5,73 & 5,73 \\
\hline & & 150 & 4,78 & 2,87 \\
\hline & & 50 & 5,73 & 7,64 \\
\hline Variasi 4 & 2 & 100 & 3,82 & 4,78 \\
\hline & & 150 & 4,78 & 6,69 \\
\hline
\end{tabular}

Sumber: Hasil Pengujian (2020) 


\section{Effek Rasio}

Fiber aspect ratio adalah perbandingan antara panjang fiber (1) dan diameter (d). Dari penelitian terdahulu (Sudarmoko) penggunaan aspek rasio serat yang tinggi akan mengakibatkan terjadinya balling effect, yaitu penggumpalan serat membentuk suatu bola serat dimana serat tidak tersebar merata. Oleh karena itu disarankan penggunaan serat dengan aspek rasio rendah $(1 / \mathrm{d}<50)$, tetapi bila panjang fiber terlalu pendek pengaruh fiber akan kurang signifikan dan juga jika terlalu panjang serat yang terjadi maka akan terjadinya balling effect. Dapat dilihat pada grafik di bawah ini:

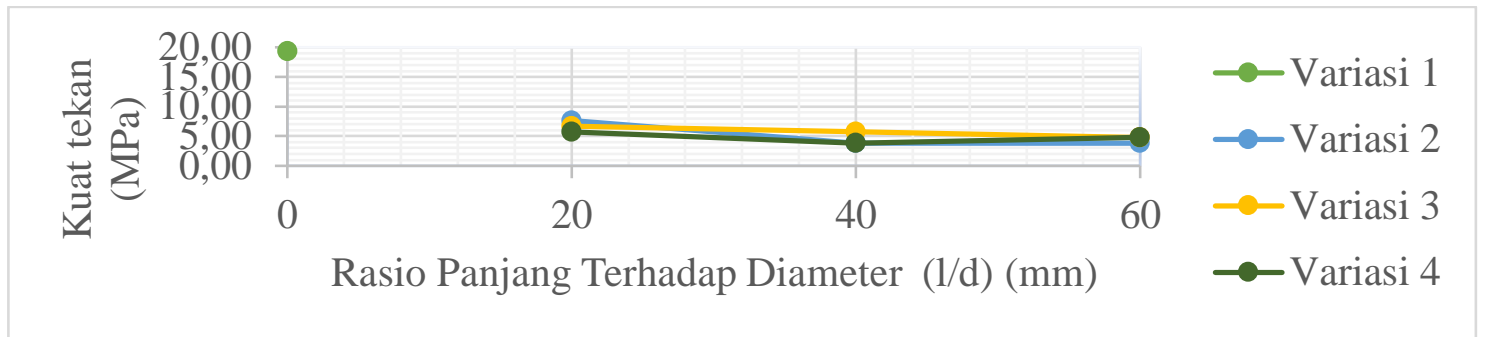

Sumber: Hasil Pengujian (2020)

Gambar 1. Grafik Hasil Hubungan Kuat Tekan Beton Umur 7 Hari Terhadap Rasio (L/D)

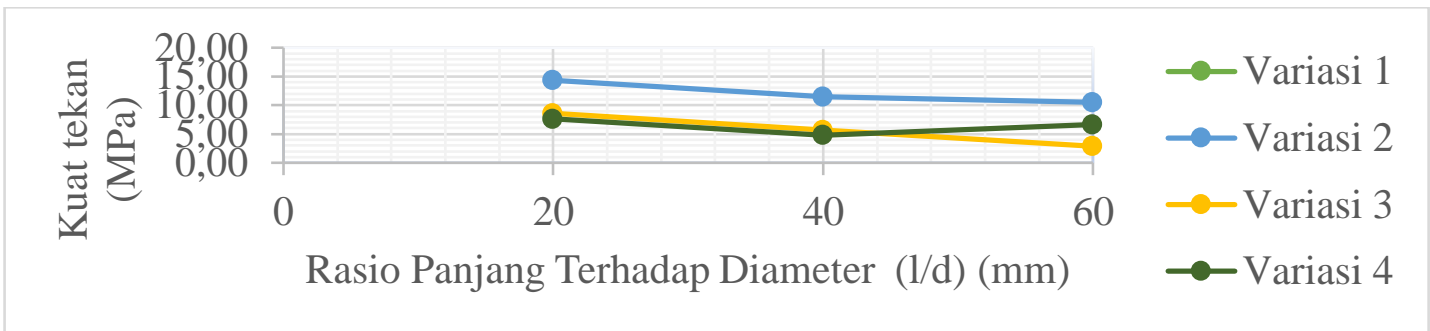

Sumber: Hasil Pengujian (2020)

Gambar 2. Grafik Hasil Hubungan Kuat Tekan Beton Umur 28 Hari Terhadap Rasio (L/D)

\section{Efek Kadar Serat}

Dari hasil pengujian bahwa hasil efek penambahan kadar serat pada beton mempengaruhi kuat tekan beton, dapat di lihat pada grafik di bawah ini:

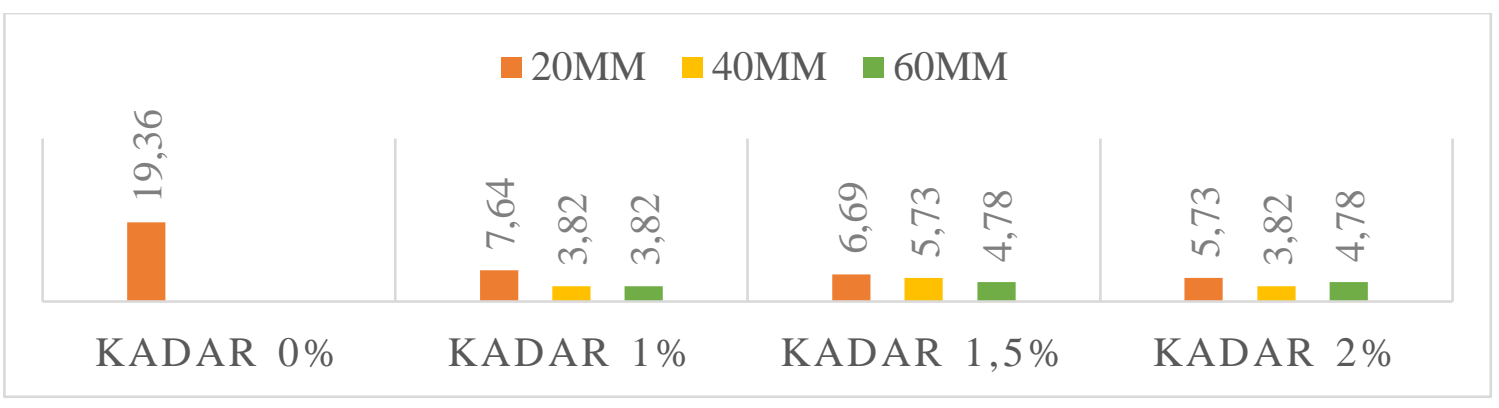

Sumber: Hasil Pengujian (2020)

Gambar 3. Grafik Hubungan Kuat Tekan Beton Umur 7 Hari Terhadap Persentase Kadar Serat 


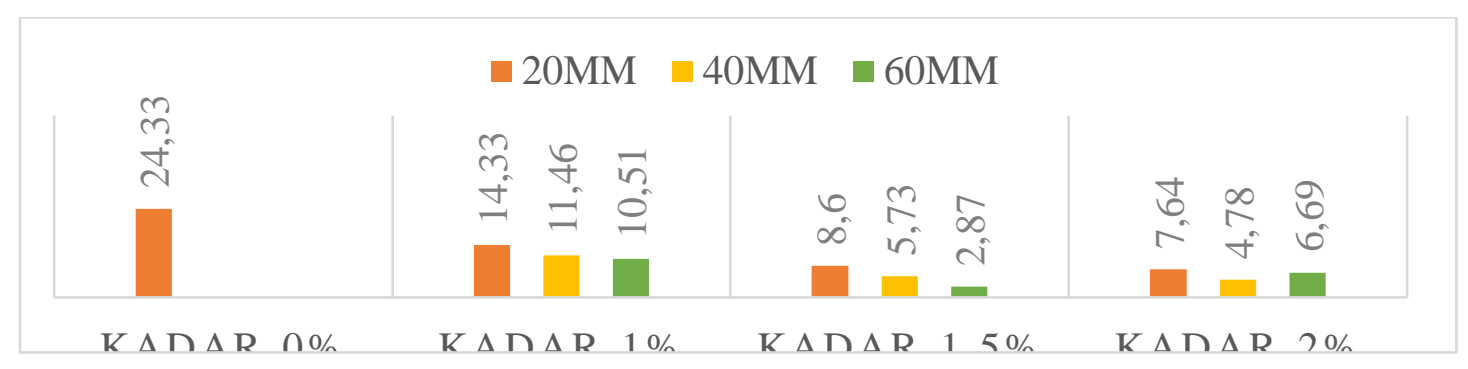

Sumber : Hasil Pengujian (2020)

Gambar 4. Grafik Hubungan Kuat Tekan Beton Umur 28 Hari Terhadap Persentase Kadar Serat

\section{Kuat Tekan Maksimum}

Kuat tekan maksium yang diperoleh pada penelitian kali ini yaitu dapat di lihat pada di bawah ini:

Tabel 8. Hasil Kuat Tekan Maksimum Beton Umur 7 Hari

\begin{tabular}{|c|c|c|c|c|c|}
\hline \multicolumn{6}{|c|}{ Umur Beton 7 Hari } \\
\hline & \multirow[t]{2}{*}{ Kadar Serat (\%) } & $\mathbf{L}$ & \multirow[t]{2}{*}{$\mathbf{D}(\mathbf{m m})$} & $\begin{array}{c}\text { Rasio } \\
\text { L/D }\end{array}$ & \multirow{2}{*}{$\begin{array}{l}\text { Kuat } \\
\text { Tekan } \\
\text { (MPa) }\end{array}$} \\
\hline & & $(\mathbf{m m})$ & & $(\%)$ & \\
\hline Variasi 2 & 1 & 20 & 0,4 & 50 & 7,64 \\
\hline \multicolumn{6}{|c|}{ Umur Beton 28 Hari } \\
\hline Variasi 2 & 1 & 20 & 0,4 & 50 & 14,33 \\
\hline
\end{tabular}

Sumber: Hasil Pengujian (2020)

Kuat tekan yang ditunjukan oleh beton yang ditambahkan serat pelepah kelapa sawit tidak mencapai kuat tekan rencana $\left(\mathrm{fc}^{\prime}=30 \mathrm{MPa}\right)$. Hal ini disebabkan antara lain agregat kasar tidak memenuhi nilai abrasi standar untuk kuat tekan rencana $30 \mathrm{MPa}$. Pada pengujian abrasi di dapat persentase kehancuran 34,5\% yang artinya agregat kasar ini hanya bisa digunakan pada beton kelas II, yang nilai kuat tekannya hanya berkisaran 10,38 $\mathrm{MPa}-18 \mathrm{MPa}$ dan metode mix desain campuran yang digunakan berpengaruh terhadap beton serat.

\section{Pola Retak atau Keruntuhan}

Pola keruntuhan yang terjadi pada benda uji ada 2 pola yaitu colummar dan cone \& shear. Keruntuhan yang dominan adalah keruntuhan (keruntuhan belah) colummar.

\section{Kuat Tarik Belah}

Berdasarkan hasil pengujian di laboratorium untuk pengujian kuat tarik belah diambil dari kuat tekan maksimum pada umur 28 hari yaitu 14,33 MPa dengan kadar serat $1 \%$ dan rasio $1 / \mathrm{d}=50$. Disini uji kuat tarik belah dilakukan untuk umur 7 hari yang terjadi pada beton serat ini sangat bagus dari pada beton konvensional, dimana kuat tarik belah pada beton serat yang didapat sebesar 2,10 MPa dan beton konvensional yaitu 2,04 MPa. Dimana dari pola retak yang terjadi terlihat bahwa setelah diberikan beban beton konvensional langsung terbelah sedangkan beton dengan penambahan serat pelepah kelapa sawit masih terikat sempurna antara beton dan serat. 


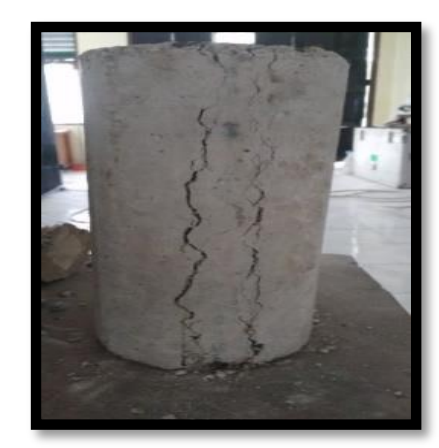

Gambar 5. Pola Keruntuhan Tarik Belah Beton

\section{PENUTUP}

\section{Kesimpulan}

Berdasarkan hasil penelitian dan pembahasan dapat diambil kesimpulan sebagai berikut:

1. Rasio panjang terhadap diameter serat ( $1 / \mathrm{d})$ dari serat pelepah kelapa sawit itu terhadap kuat tekan tidak memberikan pengaruh yang signifikan terhadap kuat tekan beton, dari hasil pengujian kuat tekan beton tertinggi terjadi dengan penambahan serat pelepah kelapa sawit diameter $0,40 \mathrm{~mm}$ dengan panjang $2 \mathrm{~cm}$ persentase $1 \%$ yaitu sebesar $14,33 \mathrm{MPa}$ lebih kecil dari beton tanpa serat $10 \%$. Ini disebabkan panjang serat yang begitu panjang dan kadar persentase penambahan serat yang begitu tinggi.

2. Penambahan serat dari bahan pelepah kelapa sawit memberikan pengaruh yang signifikan terhadap kuat tekan beton semakin tinggi kadar serat semakin turun hasil kuat tekan.

3. Kuat tekan beton yang dihasilkan dengan menambahkan serat pelepah kelapa sawit yang dihasilkan tidak mencapai kuat tekan rencana yaitu sebesar $30 \mathrm{MPa}$. Sedangkan kuat Tarik belah beton serat pelepah kelapa sawit dihasilkan 2,10 MPa sedangakan beton tanpa serat kuat Tarik belah yang dapatkan 2,04 MPa.

\section{Saran}

Dari hasil yang didapat pada penilitan ini, untuk penelitian lebih lanjut disarankan:

1. Serat dalam beton akan dapat berkerja lebih baik apabila didukung kualitas yang baik dari material pembentuk beton yang lain terutama agregat sehingga pemilihan agregat kasar lebih diperhatikan untuk mendapatkan mutu beton yang baik.

2. Pengontrolan dalam pembuatan benda uji lebih ditingkatkan agar memberikan hasil yang lebih baik dan teliti.

3. Agar kuat tekan beton yang dihasilkan lebih baik sebaiknya digunakan rasio panjang terhadap diameter serat $(1 / \mathrm{d})$ rendah $(1 / \mathrm{d}<50)$.

4. Untuk pengunaan jenis serat dari pelepah kelapa sawit dengan diameter $0,4 \mathrm{~mm}$ dan Panjang $2 \mathrm{~cm}$, disarankan persentase serat yang ditambahkan berada pada kisaran $0,2 \%$ sampai $1 \%$ terhadap berat semen.

\section{DAFTAR PUSTAKA}

Amna,dkk. (2014), Pengaruh Penambahan Serat Tandan Sawit Terhadap Kuat Tekan Dan Kuat Lentur Beton. Fakultas Teknik Universitas Malikussaleh.

Asroni, Ali. (2010), Balok dan Pelat beton Bertulang, Yogyakarta. Graha Ilmu.

Asroni, Ali. (2010), Kolom Fondai dan Balok T Bertulang, Yogyakarta. Graha Ilmu. 
As'ad, Sholihin (2008), Teknologi Beton Serat, Dalam Buku: Potret Hasil Karya IPTEK 32 Tahun UNS Mengabdi Bangsa. Fakultas Teknik Universitas Sebelas Maret Surakarta.

Daryanto. (1994), Pengetahuan Teknik Bangunan, Penerbit: Rineka cipta, Jakarta.

Dipohusodo, Istimawan. (1999), Struktur Beton Bertulang. Gramedia Pustaka Utama: Jakarta.

Ginting, dkk. (2014), Pengaruh Panjang Serat Terhadap Sifat Kuat Tekan Batako Berpengisi Serat Pelepah Kelapa Sawit. Jurnal Penelitian STIPAP.

Hafiz, dkk. (2015), Pengaruh Pemberian Jumlah dan Rasio (L/D) Serat Bendrat terhadap Sifat Mekanik Beton. Fakultas Teknik Universitas Muhammadiyah Malang.

Meilawaty O. (2017), Buku Panduan Panduan Praktikum Beton. Fakultas Teknik Universitas Palangka Raya.

Muktar. (2016), Analisa Kekuatan Tarik Komposit Dengan Penguat Serat Pelepah Kelapa Sawit. Fakultas Teknik Mesin Universitas Bandar Lampung.

Mulyono T. (2004), Teknologi Beton. Yogyakarta.

Sudarmoko. (1989), Pengaruh Penambahan Fiber Pada Kelecakan Adukan Beton. Fakultas Teknik Universitas Gadjah Mada.

Sukirman S. (2003), Pengertian Agregat. Palembang.

Soroushian dan Bayashi, Z. (1987) Concept of Fiber Reinforced Concrete, Proceding of The Internasional Seminar on Fiber Reinforced Concrete, Michigan State University, Michigan.

Soroushian dan Bayashi, Z. (1987) Fiber Reinforced Concrete: Theoretical, Concept and Structural Design, Proceding of The Internasional Seminar on Fiber Reinforced Concrete, Michigan State University, Michigan.

Tjokrodimulyo, Kardiyono. (2007), Teknologi Beton, Fakultas Teknik Universitas Gajah Mada.

Wang, C.K, dan Salmon C.G. (1990), Desain Beton Betulang. Jakarta: Penerbit Erlangga, Edisi ke 4 Jilid 